\title{
Neonatal goat's milk protein allergy - a rare cause for food protein allergy
}

\author{
YEE IAN YIK ${ }^{1}$ and ANN KEE HOW ${ }^{2}$ \\ ${ }^{1}$ University of Malaya \\ ${ }^{2}$ Hospital Serdang
}

May 27, 2020

\section{Title page}

1. Full Title of Manuscript: Neonatal goat's milk protein allergy - a rare cause for food protein allergy

2. Authors' full names: Yee Ian Yik (MBBS, MS, MRCS Ed, Ph.D.) ${ }^{1}$, Ann Kee How (MBBS, MRCP) ${ }^{2}$

3. Authors' Institutional Affiliations:

${ }^{1}$ Division of Paediatric \& Neonatal Surgery, Department of Surgery, Faculty of Medicine, University of Malaya, 50603 Kuala Lumpur, Malaysia ${ }^{2}$ Cardiology Department, Hospital Serdang, Jalan Puchong, 43000 Kajang, Selangor, Malaysia.

\section{Running title:}

Neonatal goat's milk protein allergy

Corresponding author: Prof. Dr. Yee Ian Yik (MBBS, MS, MRCSEd, Ph.D.)

Postal address:Division of Paediatric \& Neonatal Surgery, Department of Surgery, Faculty of Medicine, University of Malaya, 50603 Kuala Lumpur, MalaysiaFax: +603-79586360Phone: +60379492441Email:yiyik2003@gmail.com

Word count: 905 words; number of figures : 3

\section{Hosted file}

NEONATAL FPA manuscript line numbered.docx available at https://authorea.com/users/326836/ articles/454578-neonatal-goat-s-milk-protein-allergy-a-rare-cause-for-food-proteinallergy 


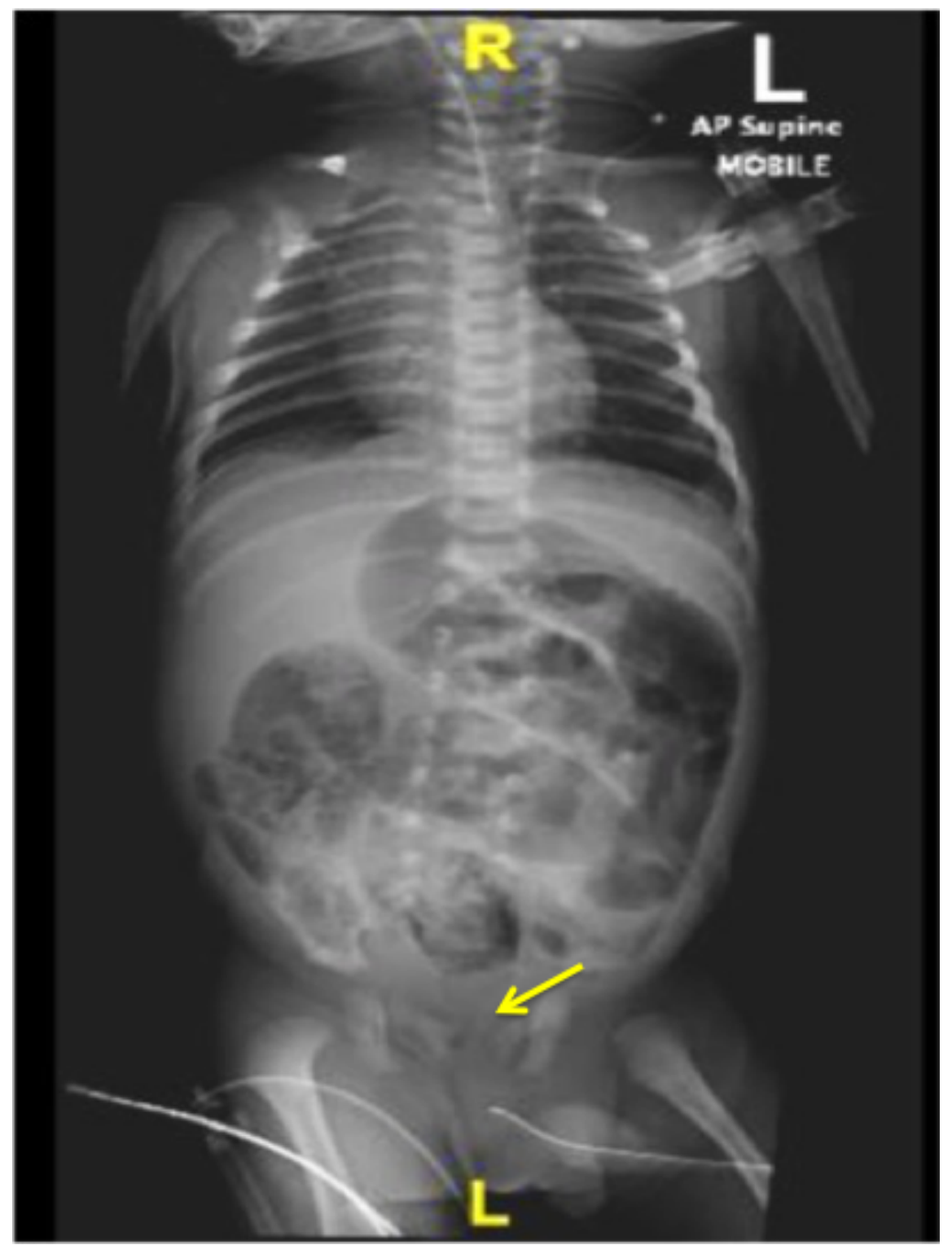



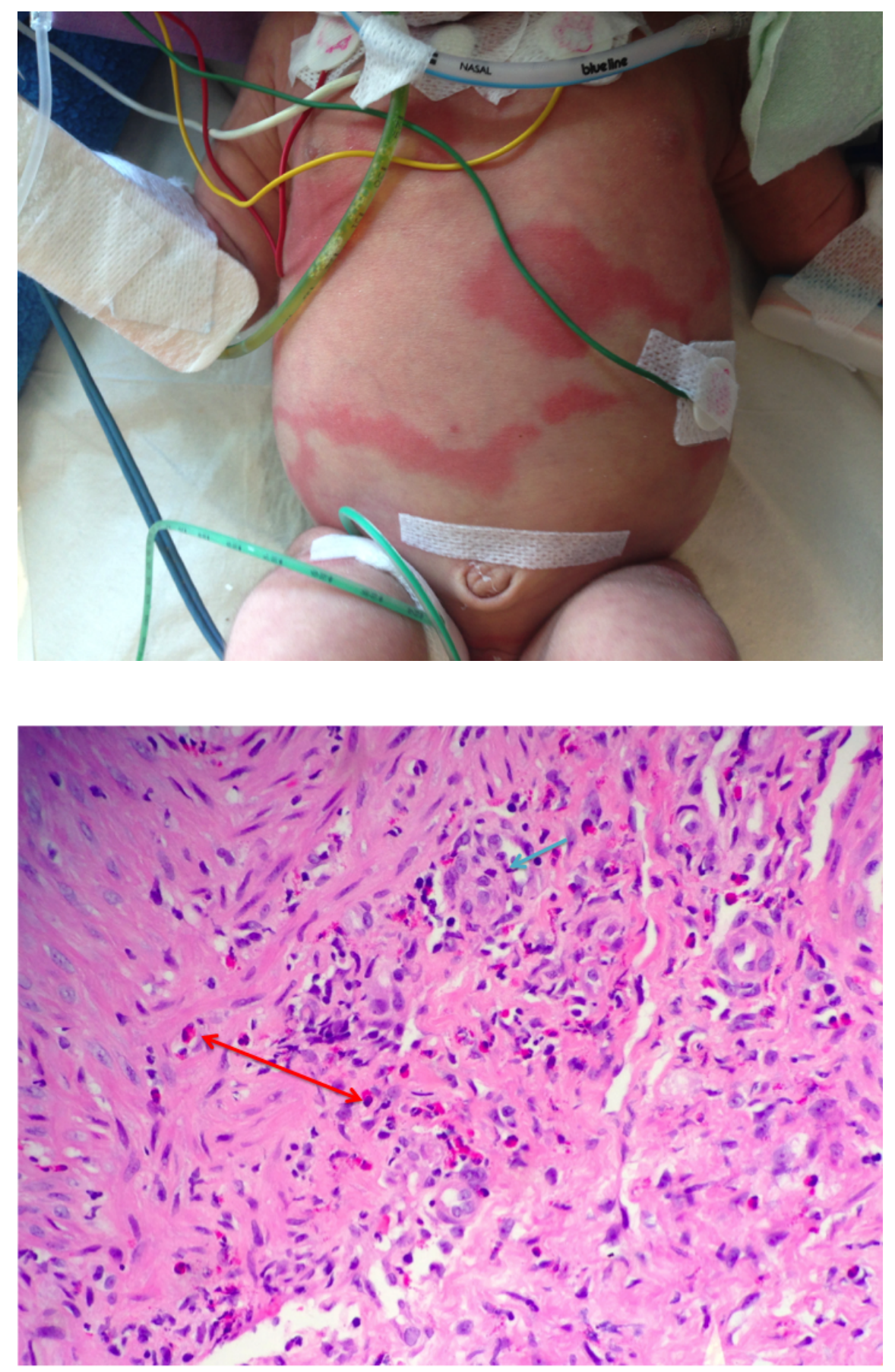